\title{
Notes on the Ciliate Boveria stevensi Issel from Galeomma turtoni Sowerby at Plymouth.
}

\author{
By \\ D. L. Mackinnon, D.Sc., \\ and \\ H. N. Ray, Ph.D., \\ From the Zoology Department, King's Colleg, London.
}

With 2 Figures in the Text.

THE little bivalve molluse Galeomma turtoni is not very common off the coast of South Devon ; but two specimens were brought in while we were working at the Marine Biological Laboratory last August, and when we examined them we found that the branchiæ and mantle cavity were aswarm with a small colourless ciliate.

A formidable list of ciliates from such situations in lamellibranchs and gastropods stands in the records. From Galeomma turtoni Sowerby at Naples Issel (1903) described Boveria stevensi, and there seems no reason to doubt that the organism we have found is Issel's ciliate, though the specimens in the Plymouth molluse are rather larger than those he measured.

We feel justified in publishing the following notes, since Boveria and its allies, the "Thigmotricha " of Chatton and Lwoff, show many features of interest to the protozoologist, and the descriptions of the mouth region in the smaller forms are very inadequate.

The body of our ciliate is $16-36 \mu$ long and about $16-20 \mu$ broad (the largest measurement Issel gives is $29 \times 17 \mu$ ). In side view it appears curved like an are; we shall speak of the convex surface as dorsal and of the more concave as ventral. The maximum thickness is about $15 \mu$. The aboral end, which is directed forwards as the animal swims, is a somewhat pointed lobe.* From the dorsal aspect and in profile, the opposite end appears obliquely truncate : this is the region of greatest breadth and

* De Morgan (1925) and some other observers regard this end in Ancistrum and Boveria as fosterior, because the mouth lies at the opposite pole. Maupas (1883) and Cheissin (1931) consider that, as the aboral end is directed foremost, it should be called the anterior end. We prefer to use the terms "oral " and " aboral " to indicate which pole we refer to, without committing ourselves further. It should be noted that the young vorticellid, when liberated from its stalk, swims aboral end foremost; yet it is customary to speak of the oral end of the stalked stage as " anterior." 
thickness. The body does not seem to be very contractile, but preserved ciliates are almost always somewhat shorter and thicker than living ones : the measurements given above were made on preserved material.

The whole surface is covered with longitudinal rows of fine cilia; there are 10-12 rows on the dorsal side and about the same number on the ventral. Their distribution is best indicated by the lines of basal granules

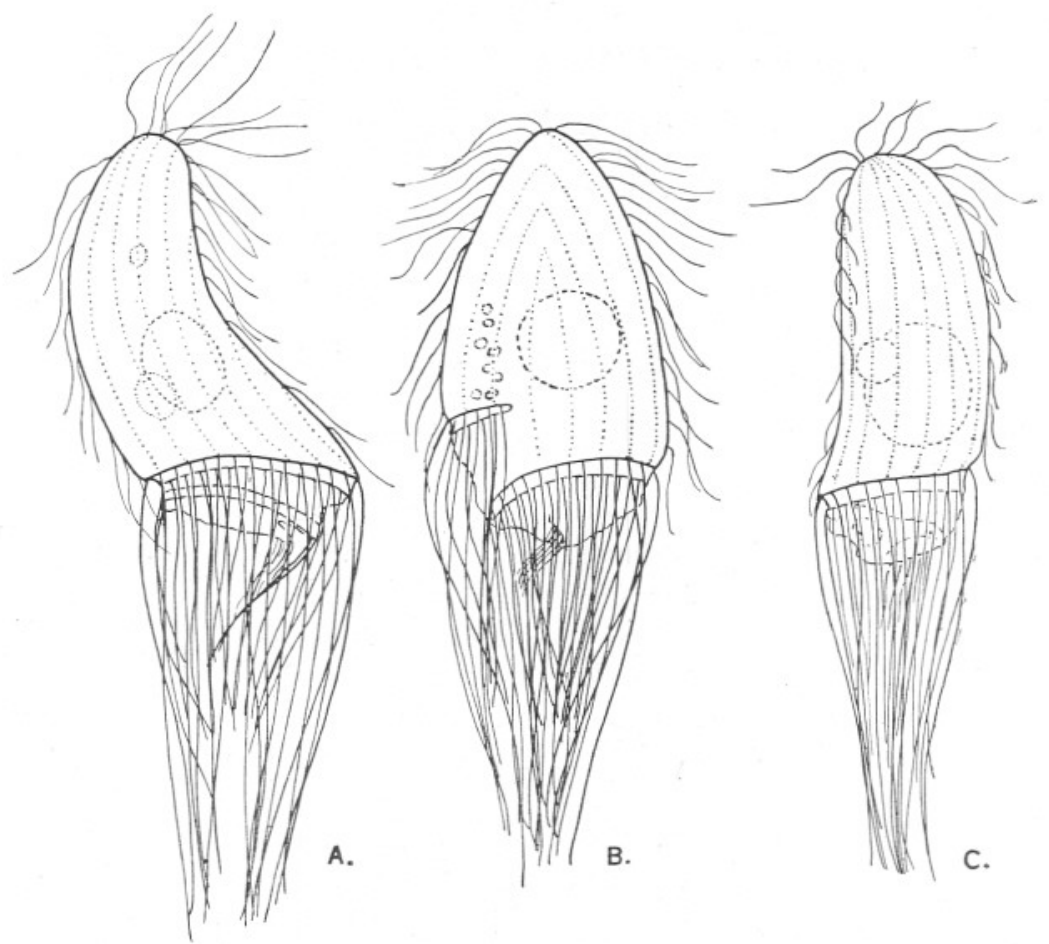

Frg. 1.-Three aspects of the living ciliate. From free-hand sketches. (The number of longitudinal lines of cilia on the body is actually greater. See Fig. 2.)
A. in profile.
B. ventral view.
C. approximately dorsal view. $\times 1200$.

in stained specimens (see Fig. 2). We find that the ventral lines convergeand meet one another at an acute angle, a short way behind the aboral end. Issel (1903) does not show this, and Cheissin (1931) suggests (p. 286), that in this respect his new genus Tiarella differs from the species of Boveria hitherto described. The most anterior of these body cilia are longer than the others and tend to stand more erect than do those further back ; just ventral to the aboral end, they are especially active and theirmovement creates a sort of vortex. These cilia seem to correspond to the 


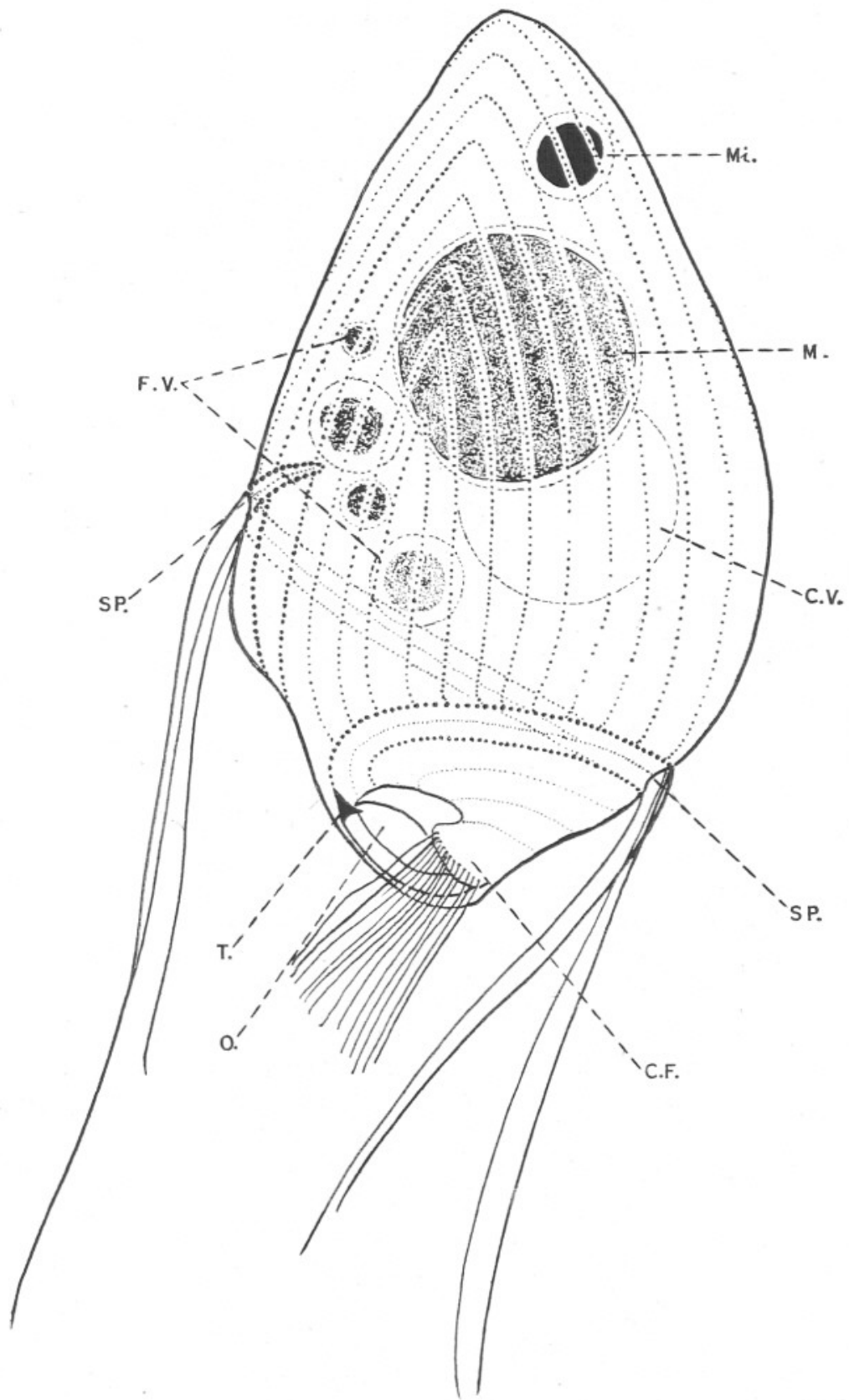

FIC. 2.-Approximately ventral view of a ciliate slightly tilted backwards to show the right-handed spiral in the adoral zone. Drawn with the aid of a camera lucida from an iron-hrmatoxylin preparation. Most of the cilia are omitted.

C.F. ciliated flap.

C.V. contractile vacuole.

F.V. food vacuoles.

Mi. micronucleus.
M. meganucleus.

O. mouth.

SP. spiral of long cilia.

T. "tooth." 
group which, throughout the Ancistridæ and their allies, are said to function as anchors to the substratum. Chatton and Lwoff (1923) make a great point of this "thigmotactic" apparatus, and go so far as to create a special subdivision, Thigmotricha, to include the Ancistridæ, Hypocomidæ, and Sphenophryidæ. They state that the thigmotactic cilia are absent in the genus Boveria, closely allied to the Ancistridæ though that ciliate undoubtedly is. We never saw the organism attach itself by these cilia while alive, but in sections through the gill tissue of Galeomma we have found a few ciliates applied to the epithelium by the ventral patch.

From the truncate oral end arises a tufted veil of very much longer and stouter cilia, which surround the mouth and are undoubtedly concerned with food-capture, though they may also contribute to the swimming movements. Figure 1 gives some idea of the appearance of the living ciliate.

Boveria stevensi swims very rapidly, turning round and round on its long axis as it goes; sometimes it glides forward, concave side downwards. As it swims, the long peristomial cilia are directed back, and form a sort of tail; but every now and then the animal pauses, and before darting off again, it raises and lowers the peristomial fringe with a characteristic " grasping" movement.

When the ciliate from Galeomma is alive it is impossible to discover exactly how these adoral cilia are arranged. But stained preparations make the general distribution clear enough, although the details can be determined only after careful comparison of many specimens seen and drawn from all aspects. We find here, as in other Boveridæ, that the peristomial cilia are arranged along a line that follows a right-handed spiral course. There is a double row of these cilia, and, in the slight gutter between them, appears in stained preparations a faint line of minute siderophilous granules from which we could discover no cilia arising.

The cilia in the posterior row of the spiral band are slightly more delicate than those in the line in front; in the immediate neighbourhood of the slit-like mouth they are finer still and a good deal shorter. To one side of the mouth projects a small, pointed flap, and the cilia bordering this move backwards and forwards as one group and very energetically; undoubtedly their duty is to drive food into the slit, though we did not actually observe the entry of any particles. Some specimens contained many vacuoles with food-balls, consisting apparently of bacteria. The mouth margin is further complicated by the presence of a minute siderophilous " tooth " arising near the base of the flap from the more anterior of the two lines of adoral cilia. The relations of these parts to one another is shown in Fig. 2. It seems worth while recording these details, since Issel found the organism too small for him to trace the fate of the spiral 
in the mouth region- " ma di quest' ultimo tratto, stante la piccolezza del materiale, non sono riuscito a formi un concetto ben sciuro" (Issel).

Dorsal to the meganucleus and towards the posterior end of the body is a large vacuole, which presumably is a contractile vacuole, though we did not observe any pulsation.

The resting nucleus is circular or ovoid in outline and measures about $8-10 \mu$ in greatest diameter. It lies about the middle of the thickest portion of the body, and towards the ventral side. In stained specimens its margin is often slightly lobed; the interior is granular and densely staining. The micronucleus is small and spherical, $3-4 \mu$ in diameter, and lies some way anterior to the meganucleus.

The great majority of the ciliates measure about $35 \times 20 \mu$. But we have found some that were only half as long, and this suggests that there may have been recent transverse fission. Hoping to find some clue to the mode of origin of the spiral in the daughter organisms, we searched our preparations for dividing ciliates. Many of the larger ones showed signs that their nuclei were initiating the division. The meganucleus in these individuals had increased in diameter $(14 \mu)$ and had lost much of its staining property ; the micronucleus was either bean-shaped, diplococcuslike, or in two lobes connected by a short, pale-staining band. We failed to find any later stages in the division process. Stevens (1904) states that in Boveria subcylindrica fission is oblique ; the peristome and contractile vacuole disappear and are formed anew in the daughter animals; "the new peristomial cilia appear on the side as a straight band which gradually assumes a terminal position, beginning to coil at the distal end."

A word as to the systematic position of Boveria. Boveria stevensi Issel seems to be distinguished from B. subcylindrica Stevens mainly by the fact that its peristomial line of cilia runs much more obliquely to the long axis of the body and that these cilia are not of such uniform length. In these respects $B$. teredinidi Nelson more closely resembles the typespecies. To include the species of Boveria, Pickard (1927) formed the family Boveridæ, of equal value with the Ancistridæ.

The earlier observers regarded Ancistrum and all its near allies as holotrichous ciliates, related to Pleuronema. Chatton and Lwoff (1922 and 1923) still consider the Ancistridæ as " specialised holotrichans." Stevens' discovery of the adoral spiral in Boveria decided her to remove that genus to the Heterotricha ; Pickard (1927) created a new family, Boveridæ, for its inclusion. Cheissin's new genus Tiarella also seems to belong to that family. But the Ancistridæ and the Boveridæ have so much in common that, if the Boveridæare to be regarded as heterotrichous, so also must the Ancistridæ.

But is Boveria a true heterotrichan? All observers have described it as NEW SERIES.-VOL. XVII. No. 2. JUNE, 1931. 
having a right-handed spiral of peristomial cilia - a feature characteristic of the Peritricha (with the exception of Lichnophora and its allies). All true Heterotricha are supposed to have the peristomial spiral wound sinistrally. On this ground Cheissin (1931) goes so far as to say that the Ancistridæ and Boveridæ should be regarded "wahrscheinlich als Abzweigung der primitiven Peritricha."

\section{REFERENCES.}

Chatton, E. and Lwoff, A. (1922 and 1923.) Sur l'évolution des infusoires des lamellibranches. C. R. Acad. Sc., Vols. 175 and 177.

Cheissin, E. (1931.) Infusorien Ancistridæ und Boveridæ aus dem Baikalsee. Arch. f. Protistenk, Bd. 73.

Issel, R. (1903.) Ancistridi del Golfo di Napoli. Mitt. Zool. Stat. Neapel., Bd. 16.

Maupas, E. (1883.) Contributions à l'étude morphologique et anatomique des infusoires ciliés. Arch. Zool. Exp. et Gén., Sér. 3, Vol. I.

Morgan, W. DE. (1925.) Some marine ciliates living in the laboratory tanks at Plymouth. Journ. Mar. Biol. Assoc., Vol. 13, p. 600.

Nelson, T. (1923.) On Boveria teredinidi s. nov. from the gills of Teredo. and of Bankia. Anat. Rec., Vol. 26.

Pickard, E. (1927.) The neuromotor apparatus of Boveria teredinidi. Univ. Cal. Publ. Zool., Vol. 29.

Stevens, N. (1901.) Ciliate infusoria. Proc. Calif. Acad. Sc. Zool., Vol. 3.

(1903.) Further studies on ciliate infusoria, Lichnophora and Boveria. Arch. f. Protistenk, Bd. 20. 